\title{
Indigenous Water Governance in Australia: Comparisons with the United States and Canada ${ }^{\dagger}$
}

\author{
Julie H. Tsatsaros ${ }^{1,5, *}$, Jennifer L. Wellman ${ }^{2}$, Iris C. Bohnet ${ }^{3}$, Jon E. Brodie ${ }^{4}$ and \\ Peter Valentine $^{5}$
}

1 Natural Resources Management Department, New Mexico Highlands University, P.O. Box 9000, Las Vegas, NM 87701, USA

2 Wyoming Established Program to Stimulate Competitive Research (EPSCoR), University of Wyoming, Laramie, WY 82071, USA; jwellma2@uwyo.edu

3 College of Marine \& Environmental Sciences, Centre for Tropical Environmental and Sustainability Studies, James Cook University, Cairns, QLD 4870, Australia; iriscbohnet@gmail.com

4 ARC Centre of Excellence for Coral Reef Studies, James Cook University, Townsville, QLD 4811, Australia; jon.brodie@jcu.edu.au

5 College of Science \& Engineering, Centre for Tropical Environmental and Sustainability Studies, James Cook University, Townsville, QLD 4811, Australia; peter.valentine@jcu.edu.au

* Correspondence: jtsatsaros@nmhu.edu; Tel.: +1-505-454-3033

+ Note: in this paper, using the term 'Aboriginal people' or 'Aboriginal person' has been recommended by the Australian Aboriginal Advisory Group of Community Legal Centre's NSW because they are "more positive and empowering terms". We also use the term "Indigenous"; 'Indigenous' is still commonly used to refer to Aboriginal people, to avoid repetition of the word 'Aboriginal'. The UN Nations World Summit on Sustainable Development started using the term "Indigenous peoples" for the first time in its official political declaration in 2002. "Native American" refers to the Indigenous peoples of the Americas and came into widespread common use during the civil rights movements of the 1960s and 1970s. The term "Indian" is still widely used today in the U.S. The Canadian government has formally adopted use of the term "First Nations" and "Aboriginal peoples." In Canada, the terms (above) are formal categories, but many prefer "Indigenous" as a more inclusive term to refer to "First Nations", "Inuit" and "Metis". The term "Tribes" is used when discussing the U.S. context but is not used very much in Canada. At times in this paper, the term "Tribe" is used in one context (specifically when discussing the U.S.) but not in other contexts.

Received: 16 August 2018; Accepted: 9 November 2018; Published: 13 November 2018

\begin{abstract}
Aboriginal participation in water resources decision making in Australia is similar when compared with Indigenous peoples' experiences in other common law countries such as the United States and Canada; however, this process has taken different paths. This paper provides a review of the literature detailing current legislative policies and practices and offers case studies to highlight and contrast Indigenous peoples' involvement in water resources planning and management in Australia and North America. Progress towards Aboriginal governance in water resources management in Australia has been slow and patchy. The U.S. and Canada have not developed consistent approaches in honoring water resources agreements or resolving Indigenous water rights issues either. Improving co-management opportunities may advance approaches to improve interjurisdictional watershed management and honor Indigenous participation. Lessons learned from this review and from case studies presented provide useful guidance for environmental managers aiming to develop collaborative approaches and co-management opportunities with Indigenous people for effective water resources management.
\end{abstract}

Keywords: water resources; Indigenous; co-management; policies; water rights 


\section{Introduction}

Indigenous communities throughout the world have long histories and experience in managing their lands and waters. However, since European settlement of Australia and North America, the western scientific approach to natural resources management (NRM) has become the dominant approach to managing land and seascapes [1]. This ideological hegemony set the tone for water resource management and perpetuated political and cultural alienation by aligning policy and relationships according to colonial governments. In most cases, this resulted in attempts by colonial government cultures to override the cultural and traditional relationship to water held by Indigenous people.

While connections between NRM, Indigenous peoples' customary law systems and their relationships with the land and sea (including cultural obligations to their country) still exist, they have been marginalized and, in some cases, invisible for quite some time. Greater recognition of the rights of Indigenous peoples and regulations mandating public participation in water management have provided some opportunities for Indigenous peoples to be involved in ongoing negotiations related to water management $[2,3]$.

Despite certain limitations and challenges, it is vital for Indigenous peoples to be involved in water management negotiations. Studies have shown positive associations between Indigenous involvement in NRM and social well-being [1,4]. Furthermore, Indigenous peoples have managed and maintained their traditional lands (and sea) sustainably over long periods of time [5]. Co-management of water resources affords Indigenous peoples the right to collaboratively work toward a common goal and achieve varying levels of community participation while working on interjurisdictional, watershed issues. Co-management is an on-going process and requires issues to be constantly clarified, explained, negotiated and understood by all stakeholders [6]. There must also be a broad sharing of power and responsibility between governments and resource users. This can be achieved by building linkages and decision-making structures within the management domain [7] (p. 119).

As a component of co-management, it is critical to realize that water does not follow jurisdictional, cultural, and economic boundaries. The importance of legitimacy, transparency, and accountability in decision making is fundamental to sharing a finite resource within common watersheds. This is not the case of one government dominating over another; rather, it should reflect collective decision making, self-determination, and adaptive process that allows for social and environmental justice to play a larger role in water governance [8]. Perhaps Article 11 of the UN Declaration on the Rights of Indigenous Peoples (UNDRIP) could be incorporated into water laws and policies in Australia and North America to provide a framework that evaluates tools and approaches for Indigenous involvement while also providing Indigenous economic opportunities in water. Some frameworks in Western Australia that have encompassed significant factors for successful co-management have proven to be robust when evaluated against international standards for best practice. These successful models are discussed in more detail in subsequent sections of this manuscript.

We provide a summary of the key literature that examines governance approaches (legal and voluntary) to Indigenous involvement in water planning and co-management. This paper's main focus is on Australia, with important references to Canada and the U.S for purposes of discussion. This summary details governance frameworks, legislative policies and practices, and provides case studies in three country contexts to highlight and contrast Indigenous peoples involvement in water resources planning and management in Australia and North America. We also provide several examples of key Indigenous entities in Australia and North America that are active in land and sea management, governance and water rights leading to successful co-management partnerships while ensuring distinctive management approaches have been respected and coordinated.

These co-management models provide important illustrations of Indigenous rights and interests that are helping resolve conflicts and respect uses while providing effective management of water resources at various scales. We advocate advancing cooperative approaches to water planning and management gained from lessons learned from this review while improving collaboration and effective water resources management with Indigenous people. 


\section{Key Indigenous Water Resources Management and Governance Frameworks}

Although the legal and political bases for Indigenous dispossession have varied among the post-settler states, they had the common result of creating 'reserves' and 'reservations' as diminished land bases for the remaining Indigenous population. These lands typically represent a portion of what previously constituted the custodial lands of pre-colonial Indigenous populations [9].

As former British colonies, Canada, Australia and the U.S. share the legacy of English common law [10]; they also share parallels in history and governmental policies to limit and block Indigenous peoples access to traditional resources [1]. Indigenous peoples in North America and Australia have sought to reclaim management over their traditional territories and restore native title rights and jurisdictional boundaries. This process has taken different paths in Canada, Australia and the U.S.; however, common themes include contestation over sovereignty, territory claims for Indigenous rights, titles to land and water repatriation for past injustices, and reconciliation based on formal recognition [10]. All these examples highlight the need for government-to-government consultation and respect for Indigenous peoples' perspectives and values. Recognition and treatment of Indigenous Nations/First Nations as governments on par with colonial governments is, at least within the U.S., an official mechanism of consultation and collaboration.

While a common history and legal heritage provide a basis for comparing Indigenous peoples access to traditional resources, it is also necessary to consider the cultural, economic, social and political differences between Indigenous peoples in North America and Australia. In North America, for example, many Indigenous groups have hierarchical social and political structures, unlike the non-hierarchical clan-based societies of Indigenous societies in Australia. Additionally, at the time of British colonization, Australia was occupied almost exclusively by hunter-gatherer societies, whereas North America was occupied by more diverse Indigenous economies, including agriculturally based communities (e.g., Pueblos' historic irrigation structures).

Treaties in North America have been important elements in negotiations with Indigenous peoples in North America [1,11]. There has been formal recognition of Indigenous peoples as entities in sovereign states, unlike in Australia where no treaty documents or treaty proposals have official recognition $[1,12]$.

Despite the cultural, economic, social and political differences between Indigenous peoples in North America and Australia, there are important parallels in the ways Indigenous peoples have sought to actively participate in water resources management initiatives. New approaches (including consensus-based agreement making tools) have given Indigenous peoples better opportunities to participate in water resources management decisions [12].

A main distinction that has emerged from each of these countries is the use of formal and informal frameworks to guide negotiations. There are well developed models in Canada and the U.S., but the frameworks are less developed in Australia [10]. Although the history of relations between colonial and Indigenous peoples in Australia and North America is similar; "a significant difference is the establishment of treaties between the Federal Government and Indigenous nations in North America" [1] (p. 200). In the U.S., treaties signed in the mid-1800s between the Federal Government and individual tribes often set the tone for water rights negotiations in the 1990s and 2000s. The U.S. Government, unlike Canada and Australia, acts as "trustee" to Native American tribal land which, despite its paternal overtone, theoretically creates a government-to-government relationship whereby the tribes join a process that includes consultation on matters regarding natural resources. However, this does not often play out as such in practice. This is particularly so given histories of inequality and dispossession, as well as administrative and bureaucratic structures which reinforce federal and state authority over certain domains.

In the U.S. and Canada, courts have identified that native title is a source of fiduciary obligations owed by governments to groups of Indigenous people of those countries [13]. Toohey J. of the High Court in Mabo v Queensland (No. 2) in Australia "found that a fiduciary obligation arises on the part of the Crown, and whether or not a claim for fiduciary duty may succeed is still an open issue" [13]. 
In Australia, recognition of traditional 'native' title occurred more recently. Aboriginal Australians, Indigenous Canadians and Native Americans are continuing to affirm their rights and responsibilities to natural resources of their lands and seas be restored, as this is basis for their cultural identity and well-being.

This review of the key governance approaches, policies and practices does not intend to provide an exhaustive list of all available mechanisms that can be used in developing a framework for Indigenous participation in water resources management. Rather, these instruments offer several illustrative directives and declarations for Indigenous involvement in water resources management in Australia, the United States and Canada.

\subsection{Australia}

'Caring for Country' is the term used by Australian Indigenous peoples to denote Indigenous involvement in management of their lands and seas [7]. These landscapes and waterways provide healing places and story places as well as important food sources. Therefore, Indigenous people expect to participate fully in management decisions [14]. In the Northern Territory (NT), for example "approximately $85 \%$ of the coastline and $44 \%$ of the total land mass are held under Aboriginal title" [15] (p. 105). Marshall states "Article 11 of the UN Declaration on the Rights of Indigenous Peoples (UNDRIP) should be incorporated into Australia's water laws and policies in addition to Article 20 (for Indigenous peoples) to develop economic opportunities in water" [16] (p. 221).

Land rights are still a recent phenomenon in Australia and the exact nature of the rights conferred has not yet been worked out to the extent we see in Canada, the U.S. or New Zealand as described in Escott et al. [17]. Until recently, Indigenous knowledge, despite its relevance to sustainability, has not frequently been used in water management and most jurisdictions in Australia do not have in place effective practices for Indigenous engagement. In addition, the recent high frequency of change in both Federal and State governments has led to discontinuous policy-setting [18], especially since the different persuasions of government have very different development-environmental protection approaches. However, rather than using land rights directly, many Indigenous groups are using the normal legal avenues of appeal open to third parties, against developmental approvals for operations such as new mines. In some cases, negotiated agreements can be reached [19] which may prove more useful than decisions handed down by courts.

An example of the complexity of using land rights to appeal against large development proposals is the hugely controversial Australian Adani Carmichael thermal coalmine proposal in central Queensland [20]. This mine, if it moves forward, will be the largest coal mine in Australia. Concerns about the mine include contributions to global greenhouse gas emissions and severe impacts to the Great Barrier Reef [21-23]. The port of Abbott Point is a controversial dredging project inside the Great Barrier Reef World Heritage Area, required to handle the increased coal export from the mine [24,25]; this potentially creates severe effects on the water resources (both surface and groundwater) surrounding the mine site [26], and its "social license to operate" [27]. Indigenous traditional land owners (the Wangan and Jagalingou Peoples) have developed "Indigenous Land Use Agreements (ILUA)" with Adani but other Indigenous rights holders have challenged these in court [28]. These other Traditional Owners outright reject the ILUA between the Wangan and Jagalingou Peoples and the Adani Mining Company. As Morgan and Cole-Hawthorne note:

The ILUA process in Australia that seeks to aid the engagement and empowerment of Traditional Owners is only a negotiation process. There is no right to veto, because such development is assumed to be in the public interest. For the Traditional Owners, their knowledge to Country tells them this development is wrong. The mine will destroy the health and balance of Country, no matter what compensation is provided. This knowledge has no place in the discussion, because it challenges the assumptions of the 'public interest' - the neo-liberal assumption that the development is good. [29] (p. 54) 
Court cases brought by Traditional Owners in Australia based on human rights, as well as appeals and court cases on environmental grounds [28] continue, but currently (as of late 2018), none have been successful. Reddy and Rosencranz claim that "It seems evident that the courts have been shockingly strict in interpreting laws to disadvantage the environment, the native peoples, their culture and customs and the global fight against climate change" [28] (p. 33).

Unlike Canada and the U.S., Australia has not developed a mandate to include or recognize Indigenous water rights nor strengthened their government departments to substantially open the dialogue with Traditional Owners. Also, distinct from Canada and the U.S., there are no treaty documents or treaty proposals officially recognized for Indigenous water rights in Australia. Further, land and water rights in Australia are currently legally separate; however, many Indigenous people hold a belief that water cannot be separated from the land [30]. Given a lack of jurisdictional and sovereign status in federal government policy, in some ways the overall situation of Indigenous legal recognition is fragile, especially in comparison with some counterparts in Canada and the U.S. The main difference is due to their inherent jurisdictional and sovereign status recognized by federal government policy [10].

Indigenous water rights are currently recognized by statutory land rights regimes including Native Title based on the Mabo v Queensland (No. 2) (1992) (175 CLR 1) case, and the Commonwealth Native Title Act, as well as other statutory protections and rights [31]. Native title is defined by the Native Title Act to be the "communal, group or individual rights and interests of Aboriginal peoples or Torres Strait Islanders in relation to land or waters" [15] (p. 107). The Native Title Act (1993) was enacted by the Federal Government to provide for certainty for land administration throughout Australian jurisdictions for negotiations in relation to native title and the determination of native title claims [32].

Following the High Court's Mabo judgment and the passage of the Native Title Act (Cwlth), more land has been claimed by Indigenous Australians [15]. It is now estimated that close to $20 \%$ of Australia is Indigenous owned, and a large proportion of that land base is found in the tropical rivers region of Northern Australia [15]. In the Kimberley region of Western Australia, Indigenous people hold a significant proportion, approximately one third of the total number of pastoral leases [14]. Indigenous participation in water resources management is especially important in Northern Australia, given the current extent of Aboriginal land ownership, and potential for an increase of native title claims over the sea [32].

Recent droughts and impacts to irrigated areas of southern Australia have brought a new focus on the potential for large-scale development of marginal cropping lands in Australia's monsoonal north [33]. Northern Australia has been targeted by supporters of agricultural development for many years and land use is currently dominated by low intensity grazing of beef cattle on large properties often more than $10,000 \mathrm{~km}^{2}$ in area [33]. Indigenous land holdings are also extensive and, until recently, Indigenous concerns about northern agricultural development have been largely ignored [33].

There are calls for governments, communities and industries to work together to develop clear principles that allow for the sustainable development of water resources in northern Australia. These ideals must not only focus on food security, but also Indigenous land and water rights, and the sustainable use of water and landscapes. Developing the framework to integrate science, economics, Indigenous rights to land and water, and governance of these areas will be a major challenge [33].

Native title claims, customary resource rights, and negotiated agreements may contribute to strengthening Aboriginal control over their lands, water, and biological resources across Australia. However, "the nature and extent of native title rights and interests" for water co-management arrangements in the future remain uncertain [15] (p. 105).

Recent reports confirm that governments across Australia are in the early stages of formally recognizing Indigenous peoples relationships with water for spiritual, cultural and economic purposes. In over-allocated systems within the Murray Darling Basin for example, the failure to secure ecological outcomes from environmental water allocations has significantly impacted Indigenous interests [13] (p. 4). 
In 2013, there was a Federal Government proposal to allow Australians to vote on a referenda to modify the constitution to recognize Aboriginal and Torres Strait Islander people as the continent's original inhabitants. In December 2015, the Australian Government appointed a Referendum Council to consult throughout Australia and take next steps towards achieving constitutional recognition of Aboriginal and Torres Strait Islander people. In June 2017, the Council wrote a report to the Government detailing how the Constitution could be changed. This change could potentially assist in developing new strategies for examining Aboriginal and Torres Strait Islanders' roles in self-governance and natural resource decision-making. In 2018, the Australian Government and Opposition is still debating these major proposals and a path to move forward.

Indigenous groups are being formed to declare their rights, create inclusive processes, and develop collaborative relationships based on recognition of cultural differences, including Indigenous law, customs and economic needs. These groups are "developing their own critiques of, and positions on water policy issues such as commercial resource rights and environmental flows" [13] (p. 3). Formation of these active groups includes the Indigenous Water Policy Group and the National Indigenous Freshwater Advisory Group. Indigenous water groups create opportunities for dialogue between Indigenous Australians, the Federal Government, and state/territory governments [13].

\subsubsection{Key Australian Indigenous Governance Policies Acts and Partnerships}

A number of water resource management mechanisms in Australia were adapted to recognize Indigenous cultural values, most notably the concept of an environmental value or beneficial use under the National Water Quality Management Strategy. The legal status of native title over sea country is an emerging situation [34]. Several court judgments have provided certain rights to coastal Indigenous peoples over their traditional coastal and intertidal estates, commonly referred to as 'sea country' by Aboriginal peoples living on or near the north Australia coast [35]. In 2001, the High Court of Australia found that claims under the Native Title Act can be made over the sea, including intertidal zones, although these rights are non-exclusive. They can include rights to access and extract water for non-commercial purposes, the right to fish, and the right to hunt and gather from the water [35].

\section{National Water Initiative (NWI), 2004}

In signing the NWI, all Australian jurisdictions agreed their water access entitlements and planning frameworks will recognize Indigenous needs in relation to water access and management. Native title interests in water are to be considered, and Indigenous water use assessed and addressed in these plans. However, progress in meeting NWI objectives is slow in the absence of institutional arrangements to secure Indigenous outcomes [13].

Indigenous Protected Areas (IPAs)

The Indigenous Protected Area (IPA) Program has been in place since the late 1990s [36]. “The Program is a mechanism to increase the representativeness of the National Reserve System through voluntary inclusion of Indigenous estates and supports the development of cooperative management arrangements" [36] (p. 50). There is recognition in Australia that "a large area of land in natural condition was under Indigenous ownership and Australia's commitment to a comprehensive, adequate and representative reserve system was not possible without including Indigenous lands" [36] (p. 50). IPAs "are run by Indigenous groups themselves, and IPAs are recognized and supported as part of the national protected area system" [37] (p. 1131).

Many recent studies have recommended improvements to existing models and guidelines and point out the difficulties with the NWI and IPAs. Davies et al. state it is too early to assess whether IPAs are working well but there are likely ways of improving them through longer-term research [38].

Lee states that currently, IPAs seem to be working and "no IPAs have been delisted even with concerns raised in the first national review of IPAs as to the potential longevity of IPAs and the focus on governance relationships as opposed to strict conservation goals" [39] (p. 367). 
The Global Support Initiative for Indigenous Peoples and Community-Conserved Territories and Areas (ICCA-GSI) was formed to "broaden the range and quality of diverse governance types in recognizing ICCAs. ICCA-GSI's objectives are to improve the recognition and overall effectiveness for biodiversity conservation, sustainable livelihoods and resilience to climate change effects of territories and areas conserved by Indigenous peoples and local communities" [40].

Davies et al. identified four types of innovations in some recent IPA plans that reflect improved socio-cultural and political characteristics of these ICCA's. These include:

(1) A focus on customary institutions in governance;

(2) Strategic planning approaches that respond to interlinkages of stewardship between people, place, plants, and animals;

(3) Planning frameworks that bridge scales by considering values and issues across the whole of an Indigenous people's territory; and

(4) Varied communication modes appropriate to varied audiences, including an emphasis on visual and spatial modes [38] (p. 1).

\section{State Indigenous Governance Policies}

The Federal Government's Native Title Act (1993) applies to all states and territories; however, legislative mechanisms for specific Indigenous engagement are found in only three Australian jurisdictions: New South Wales (NSW), Western Australia (WA), and Queensland (QLD) [13,14]. In WA, Indigenous representation is required only for the lowest rung of statutory plans [13]. Hill states "In the Kimberley region of Western Australia, Miriuwung-Gajerrong people initiated a Cultural Planning Framework to help achieve greater equity in planning for co-management of the first Indigenous-owned protected areas managed with the state" [41] (p. 72).

\subsubsection{Key Indigenous Organizations}

This section highlights two important examples of key Indigenous organizations in Australia that are active in Indigenous land and sea management, governance, and water rights, emphasizing positive examples for Indigenous co-management opportunities.

North Australian Indigenous Land and Sea Management Alliance (NAILSMA)

Recognizing the need to support culturally appropriate livelihoods and to better coordinate Indigenous land and sea management and development across north Australia, in 2001 senior Indigenous leaders of major Indigenous organizations formed the NAILSMA. NAILSMA's mission is to support Aboriginal and Torres Strait Islander land and sea management using strategic approaches to care for country, with an emphasis on practical management by Traditional Owners across northern Australia [17].

Girringun Aboriginal Corporation

Girringun Aboriginal Corporation is in northeastern Queensland, and governance and management of both freshwater and saltwater country is central to Girringun's work. Several tropical rivers form part of the Girringun region and Traditional Owners are concerned with water quality issues in these waterbodies [42-47]. A long-term goal for Girringun is to co-manage their traditional homelands with other recognized jurisdictional stakeholders.

\subsection{The United States}

Native American tribes have sovereign rights and also rely on interjurisdictional, adaptive governance to affirm the right to govern their lands and waters [48]. Over $80 \%$ of Indigenous lands in the U.S. are concentrated in eleven western states with an arid or semi-arid climate [49]. Protection and guarantee of sufficient water resources are considered vital to the economic and 
cultural survival of Indigenous communities [49]. In the U.S., Native American water rights are often recognized by the federal government, but whether these rights are "activated" or protected is often up to up to a complicated process between the federal and state governments and the tribes themselves.

The creation of Native American rights to access one resource (e.g., hunting and fishing) also carries implied legal rights to other resources (e.g., the water that sustains the animals that are hunted and fished). "As a consequence, there is no legal separation of land, water and landscape elements that depend on them (e.g., animals), and management rights are merged in law to reflect their relationship in the landscape" [30] (p. 13).

\section{Key U.S. Indigenous Water Resource Management Policies}

Current Federal Indian water policy prioritizes the negotiated settlement of tribal water claims rather than litigation, which can be a flawed, lengthy process. While many tribes have participated in negotiated agreements or settlements to advance their water rights, the future of Indian water law from the U.S. Government perspective is not always straightforward [30]. The U.S. has divergent resource allocation systems that recognize interests of Indigenous people in water use and development while, at the same time, the local system does not often encourage co-management. A lot of legal attention has been given to the scope and priority of U.S. Indigenous water rights where Aboriginal title to water has been found to be strong [30].

Treaties and Aboriginal Rights

Prior to the 1870s, many treaties were negotiated between the U.S. Government and Native American tribes. Treaties often created a right for an Indian tribe to utilize a resource, a right which may have conflicted with other non-Indigenous resource users. Indian entitlement consists of the right to prevent other appropriators from depleting the stream's water below a protected level in any area where the non-consumptive right applies. "Tribes that have historically relied on water for fishing developed an Aboriginal right to an amount of water necessary to preserve their fishing economy" [30] (p. 8).

Native American Water Adjudications and Settlements

The U.S. constitution recognizes treaties as supreme law of the land. However, some Native American tribes have had to "litigate to obtain restitution of their treaty rights" [1] (p. 200). In 1974, several tribes in the north-western U.S. (with support of the U.S. Federal Government), sued the State of Washington over treaty violations [1]. Litigation interpreted the scope of these treaties and rights of tribes to participate in resource management decisions, transforming some tribes into major players in state management decisions that affected resources throughout the western region.

\section{Federal Indian Water Rights}

Winters Doctrine Rights (1908).

The recognition that Indian tribes and their reservations have federally reserved water rights came out of a 1908 U.S. Supreme Court decision, Winters v. United States. In Winters, the court held that at the time the reservation was established, the tribes and the U.S. Government implicitly reserved enough water to meet the future needs of the reservation [50]. The court determined the priority date for Winters' rights was the date the reservation was established, theoretically establishing senior water rights for many tribes. These reserved water rights were not subject to state law; therefore, they existed whether the tribe put the water to beneficial use or not [50]. Future conflict and confusion arose when the Prior Appropriation Doctrine and the McCarran Amendment required quantification and priority dates to be assigned to tribal water uses, thereby calling into question tribal seniority in basins that competed with the state's non-Indian water users.

Theoretically, the Winters Doctrine puts tribes in a favorable position to negotiate with other water users, yet it has failed to protect them from some non-Indian water developments such as pipelines 
and dams [49]. In many cases, the U.S. Government ignored the Winters Doctrine and its own role as a federal trustee, allowing federal water projects and state diversions of water which resulted in inundation or depletion of tribal lands and destruction of Native American historic agriculture and cultural resources [49].

After over a hundred years of uncertainty, in 2017 the Ninth Circuit Court of Appeals held that the US Federal Reserved Rights Doctrine (Winters v. United States, 207 U.S. 564, 1908) applies to groundwater. The Agua Caliente Band of Cahuilla Indians v. Coachella Valley Water District case was a positive move towards full recognition that when an Executive Order established a reservation, it reserved an amount of water to fulfill the purpose of the reservation. Whether it created a permanent homeland for the tribe or reserved land and resources for future uses, Winters now includes groundwater and surface water appurtenant to the reservation.

The recent Winters decision asserted a significant victory for tribes, particularly for those near urban areas and in the arid West where every drop of water is important. The water quantity and quality issues that come with this decision is evolving water law. For tribes wishing to quantify the amount of water reserved for potential future uses and agreements, additional phases of the trial will unveil how this may impact co-management opportunities.

McCarran Amendment (1952).

In 1952 Congress passed the McCarran Amendment, an act that waives federal sovereign immunity and allows the Federal Government to be included in state water adjudications [51]. Because the U.S. acts as tribal trustee and an independent government, the U.S. participates in an adjudication process that attempts to determine, quantify, and administer tribal rights to water. Many tribes also join adjudications to assert claims on their own behalf and to have a seat at the table. The concept of federal Indian reserved rights remains, but state courts have a role in determining the extent of these rights in conjunction with other water users [50].

Arizona v. California (1963).

The U.S. Supreme Court decision, Arizona v. California, 1963, reaffirmed the Winters doctrine and established the "practicably irrigated acreage" (PIA) standard for quantifying reserved water rights on a reservation for agricultural purposes. This meant that Winters rights could account for the present and future agricultural needs of the reservation which usually resulted in large quantities of allocated water [50]. Even though many tribes were non-agricultural at the time the reservation was created, Winters and Arizona v. California established a "future use" entitlement from which tribes could potentially develop water resources for the reservation. In addition, tribal reserved water rights could include other uses of water such as domestic use, commercial or industrial use, stock watering, mineral extraction, instream flows for fisheries, cultural and traditional uses, and recreation.

\section{Prior Appropriation}

Prior Appropriation is a system of allocating water rights from a water source that is markedly different from riparian water rights (e.g., riparian water law in eastern states). Since the 1980s, water rights through the Prior Appropriation Doctrine (water law in western states) (Wyoming vs. Colorado 259 U.S. 419) have been successfully adjudicated for several Native American tribes, resulting in federally recognized negotiated settlements [52]. Under Prior Appropriation, each water right holder has a priority date and those with the earliest appropriation date (known as the "senior appropriator"), may use their full water allocation (provided the water source can supply it, if they don't impair other senior appropriators downstream [52]. However, when applied to Native American water rights, the doctrine is often tied to beneficial uses, and if the courts decide that tribes' uses are not in accordance with their notions of "beneficial use", they may not be entitled to the senior water right. 


\section{Riparian Law}

Riparian law has its origins in English common law. Under the riparian principle, all landowners whose property adjoins a body of water have the right to make reasonable use of it. If there is not enough water to satisfy all users, allotments are generally fixed in proportion to frontage on the water source. These rights cannot be sold or transferred other than with the adjoining land, and water cannot be transferred out of the watershed.

Riparian rights are only recognized in the eastern U.S. states, yet many tribes hold a similar belief; that water cannot be separated from the land. Its inherent problem is the fact that such water rights are "open ended". Its quantification and question of state involvement in its adjudication has a lot of issues [49]. As well, riparian rights are a common law rather than an Aboriginal right [53].

\section{U.S. State Indigenous Water Policies and Co-Management Opportunities}

In Washington, tribes have a co-management arrangement with the State Government. Washington has created and attempted multi-purpose agreements including combinations of species management (fish and wildlife) and area management. These agreements were negotiated to create practical solutions to legal situations in which Indigenous and non-Indigenous property rights in land, species and water co-exist [34]. In the Yakima basin adjudication, the Yakima Indian Nation benefits from instream flow water rights and substantial rights to irrigate as a result of the State of Washington v. Yakima Reservation Irrigation District.

The Timber-Fish-Wildlife Agreement is another water resources management agreement that focused mainly on five parties (industry, Native Americans, state and local governments, conservation groups). This agreement looked at logging arrangements on privately-owned forest lands across the whole state of Washington, and ways in which logging practices affect river conditions (e.g., habitats of migratory salmon and steelhead trout, and habitats of animal and bird species). This agreement has been relatively successful in tribal fisheries management [34].

The co-management framework offers an opportunity for collaboration, adaptation, and interjurisdictional understanding within formal and informal policies and practices. An excellent exemplar of self-determination within multiple tribal and federal jurisdictions is the 2010 water settlement in the Klamath River Basin in the US (Klamath Basin Restoration Agreement (KRBA)). This case involved four federally recognized tribes: the Klamath Tribe, the Hoopa Valley Tribe, the Karuk Tribe, and the Yurok Tribe. It also included hydropower companies, non-native farmers, federal agencies, and conservation groups; all wishing to utilize limited water resources in an over appropriated basin. Each entity had unique demands and constraints and, ultimately, through lengthy negotiation and collaborative dialogue, legal agreements were made despite the cross-cultural misunderstanding of the past, the endangered species requiring protection, and the need to value historic agricultural operations in the basin.

In Oregon and California, the Klamath case serves as a reminder that tribal self-governance can set the stage for negotiated agreements that value each entities' perspectives and relationships to water. The shift in legal and policy frameworks towards local capacity-building, consensus, and a non-paternal approach ultimately improved tribal self-determination and resolution of conflicts within a shared watershed.

Underscoring appropriate government-to-government consultation, the Klamath Tribes' individual sovereign status and collective power ultimately paved the way for informal and formal governance to occur. This framework for co-management represents a dynamic link between social and ecological systems in the inherent uncertainty of annual flows in a given watershed. Future prospects for similar agreements may stem from this example in the Middle Rio Grande in New Mexico, with multiple Pueblos, federal lands, urban water needs, and agriculture all playing a prominent role in water sharing agreements in times of limited supply [48].

It is important to note that the water sharing situation in the U.S. is quite complex, and the implications for tribes and native communities is partial and incomplete as demonstrated by 
on-going developments (e.g., pipelines and dams) occurring on native territories despite protests by native peoples.

\subsection{Canada}

Treaties provided the basis for much of the early relationships between settlers and Indigenous people in Canada and continue in various forms until the present. However, there are some exceptions particularly in British Columbia and the West Coast. Since 1973, comprehensive agreements or modern treaties were negotiated under federal government policy and have constitutional protection under The Constitution Act (1982) [10,49]. There is also a fragmented federal/provincial approach, in that First Nations are governed by federal policy, but most environmental or water-based policies are provincially enforced which leads to a regulatory void.

Aboriginal and treaty rights are found in the Canadian Constitution Act (Section 35) (1982). Section 35 in the Act highlights these rights, and significant agreements have been made with Aboriginal people of the Yukon and Northwest Territories, including the ratification of the Inuvialuit Final Agreement (1984), the Nunavut Land Claims Agreement (1999) and the Gwich'in Agreement $(1992)[10,49]$. It should be noted that the Inuit in Canada are under a very different umbrella than First Nations-from a policy perspective.

Indigenous rights to ownership and management of water resources when compared with other natural resources is less well defined or documented in case law in Canada. There have been no precedential court rulings on native title water rights like the Winters Doctrine in the U.S.

There are individual treatises on laws of a particular First Nation, but there is no compilation of customary water laws of Aboriginal peoples in Canada [53]. Native peoples in Canada have water rights deriving from different sources. This situation is complex and is subject to variation from region to region [49].

\section{Common Law}

Canadian riparian rights were originally based on English common law, (similar to Australia and the U.S.), but for the most part have been replaced by statutory law. In common with all riparian land owners, Aboriginal peoples whose land borders freshwater bodies enjoy riparian rights to the extent that these rights have not been eliminated by statute. However, riparian rights provide only limited rights of use to water and are complex issues in terms of rights and permitting, versus fundamental constitutional rights [53].

\section{Key Canadian Indigenous Water Resource Management Policies}

The trend toward negotiated agreements between Indigenous groups and other land and resource claimants resulted from the need to provide a solution to the dispute over land and resources often entrained by Indigenous claims [9]. Canada's approach—which has been influential in Australia—is to pursue negotiated agreements at a regional scale (which may include federal, provincial, local and first nation governments) that provide for shared resource control and access between Indigenous and non-Indigenous peoples. With limited success, this approach has been pursued in Australia under Native Title legislation [9].

Indigenous communities in British Columbia (B.C.), Canada, are increasingly gaining power in self-governance out of the necessity of employing flexible policies based on watershed-based decision making. Unlike other Indigenous communities and First Nations in Canada, B.C. enacted the Water Sustainability Act (2016) to support collaboration throughout the province. The complex social and ecological systems in this region brought forward a need to acknowledge the inefficacy of prior colonial approaches which undermined Indigenous values and governance [54].

The evolving legal and legislative frameworks in B.C. provide excellent opportunities for the rest of Canada and serve as a model for non-hierarchical watershed management that values Indigenous water governance. There are also different approaches and models being reached in other parts of the 
country-not just with respect to the new legislation in B.C. There are new approaches and models being developed in regions including the North West Territories. As Canada tended to centralize water policy and legislation based on the dominant, non-Indigenous culture, B.C. offers a glimpse at the potential for a more holistic approach to collaborative watershed management. In addition, First Nations throughout Canada deserve to be recognized as sovereign entities with unique values and jurisdictional authority [55].

Similar to the aforementioned cases in Australia and the US, Canada must do more than recognize Indigenous water users as stakeholders or interest groups. Legal rights as recognized by the Constitution Act often present difficult situations with respect to many provincial decisions and Crown authority. Recent legal cases and commitment to reconciliation are dynamically changing this situation at present, including interpretations of right. As in the U.S., there are a lot of examples where Indigenous rights and title, and also preferences in terms of land and water governance, are not being recognized and validated, often requiring these issues be legislated through the courts (e.g., duty to consult, etc.). A necessary shift must take place at the water policy reform table in order for outdated and discriminatory, colonial practices to make way for collaborative, watershed-based governance.

\section{Treaties and Aboriginal Rights}

Legal recognition and constitutional protection are the major sources of Indigenous water rights in Canada, evidenced by a priori recognition and subsequent affirmation of Indigenous politics in the broader Canadian water resources policy [10].

Calder vs. Attorney General of British Columbia (1973).

This was a landmark case that left little doubt that native water rights are a part of Aboriginal title, which includes but does not distinguish between land and water. Thus, water rights are a part of Aboriginal title and may be seen to be tied to historic and traditional uses. This right may be enough to restrain the development of major water resources projects. It was the existence of the Aboriginal title of an Indigenous population which compelled the Quebec Superior Court to issue an interim injunction restraining the James Bay Hydro Project, eventually resulting in the James Bay and North-eastern Quebec Agreements [49].

Sparrow vs. R (1990).

The Supreme Court of Canada ruled on an important decision concerning the application of Aboriginal rights under Section 35(1) of the Constitution Act, 1982 [49]. The Court held that Aboriginal rights, such as fishing, that were in existence in 1982 are protected under the Constitution of Canada and cannot be infringed without justification because of the government's fiduciary duty to the Aboriginal peoples of Canada. However, this ruling may favour contemporary rather than traditional uses of water resources by Aboriginal people.

In contrast to the U.S., a priority date for determining water rights is of no consequence in Canada, since treaty and Aboriginal rights have constitutional priority. Further, Aboriginal water rights should be free from provincial regulation, since Canada has no legislation equivalent to the U.S. McCarran Amendment (1952) [49]. However, the number of jurisdictions involved in the regulation of water complicates water rights in Canada. In addition to the two constitutionally entrenched orders of government, the Federal Government and the ten provincial governments, Aboriginal self-governments, territorial governments and municipalities also exercise control over different aspects of water. Aboriginal rights and Aboriginal title claims further complicate water rights. Water is primarily regulated at the provincial level, while Aboriginal rights cross jurisdictional boundaries. Modern treaties between Aboriginal peoples and the Canadian Government also involve the Provincial Government as a necessary party [53].

\section{Co-Management Arrangements}

Over the past 30 years, the Government of Canada and its negotiation partners negotiated a series of Comprehensive Claims Agreements (referred to in Australia as regional agreements). These include 
the James Bay and Northern Quebec Agreement of 1975, the Inuvialuit Final Agreement of 1984, and the Nunavut Agreement of 1999 [34]. These regional agreements have a historical and legal basis unique to Canada but have established a positive example to work from for countries such as Australia. These agreements provide a set of negotiated administrative arrangements over large areas of land and sea, which may be held under a combination of Indigenous, government, and other ownership [34].

Negotiation of these regional arrangements enables all parties to have a say in a robust and workable design. Canadian regional agreements include environmental management arrangements (such as co-management of particular species), and decision-making arrangements (such as procedures for dealing with new development proposals), that apply across the entire region. They also provide a mechanism for including economic and self-determination strategies [34].

A Key Indigenous Organization in the Pacific Northwest

An example of a key Indigenous organization in western Canada that is active in Indigenous land and sea management, governance, and water rights and highlights a positive example for Indigenous co-management opportunities is described below.

Skeena Fisheries Commission.

The Skeena Fisheries Commission is an organization that initiated a cooperative relationship between First Nation peoples and other fishers to build a successful co-agreement arrangement for managing aquatic resources in British Columbia. In 1981, the Gitksan-Wet'suwet'en tribal council presented a proposal to the Pearse Pacific Fisheries Commission [30] (p. 4).

The Gitksan-Wet'suwet'en established a fishery agency to provide a mechanism through which their fisheries management proposal could be negotiated and developed. "Alliances were then made between the Gitksan-Wet'suwet'en, Tsimshian and Nat'oot'en First Nation communities, to create community management arrangements asserting First Nation authority for the entire Skeena catchment" [30] (p. 7). The Skeena Fisheries Commission was then "established to plan, coordinate and establish a Skeena Fisheries Program to promote cooperation between communities, and co-management dialogues, and work towards a goal of self-governance and economic self-sufficiency" [30] (p. 7), [56].

\section{Discussion and Main Findings}

The United States and Canada have shown the creation of rights to access for one resource (e.g., hunting and fishing) also carries an implied legal right to other resources (e.g., water that sustains the animals that hunted and fished). Consequently, resource management rights (such as land, water and landscape elements) merge in law to reflect their relationship in the landscape. However, unless this legal 'merging' is understood and accounted for a priori, it leads to escalating resource management disputes.

Although water policies that underscore self-determination and tribal sovereignty are an excellent means to begin to resolve conflicts in shared watersheds, they are often far more difficult to implement. This stems from the engrained reluctance and occasional refusal by colonial governments practices or perspectives to acknowledge tribes unique cultural and spiritual relationship with water.

Post settler practices or perspectives often view water as a resource that is to be owned, managed, and exploited for gain. In contrast, the Indigenous mindset can offer interconnection, kinship, and, in some cases, a complex ontology of water that is not based on legal or political status whatsoever. Indigenous peoples may have much to transfer and modify to post settler practices and policies by way of their inherent connections to water, landscapes, and community.

Beyond the policies and ramifications of agreements lies a potential to avoid colonial hierarchies that repeat the animosity and neglect of the past. Instead, co-management offers a philosophical awareness and actualization that Indigenous people have the right to self-determination and their unique beliefs about water. Respect and meaningful consideration of these can include legal and governance aspects; in a sense, a de-colonizing paradigm that supports water governance based on Indigenous values and law [57]. 
The U.S. has not been able to develop a consistent (between states) or agreed (amongst states, Federal Government and Indigenous people) approach to tribal water rights. There are vast differences in how tribal waters are allocated, and no single policy offers widespread or uniform application of Indigenous water rights [30].

A fundamental principle of Indigenous water governance is self-determination and the right of a sovereign nation to decide how, when and where to activate their interests and defend their resources. It is clear from recent events surrounding the Water Protector movement at the Standing Rock Sioux and the Fond du Lac Ojibwe reservations that the US government struggles with properly consulting tribes and developing true intergovernmental agreements within shared watersheds. This is especially true where the commerce of gas and oil pipelines are concerned. Underscoring the need for co-management agreements in these two cases, the cultural relationship to water and its significance to self-determination continues to be poorly understood by the US government.

Canada has promoted negotiating agreements between Indigenous groups and other land and resources claimants, and efforts to allocate decision-making responsibilities and management rights for land or water to particular groups will need provisions that facilitate management partnerships between various Indigenous groups. This also may be required in Australia, particularly in the north, where many different language groups commonly co-exist in one catchment [30].

Recent court decisions in the U.S. have applied to the use of water for reasons other than agriculture, upholding the non-consumptive nature of an Indian water right to support hunting and fishing. The circumstances of Indian life and the North American approach to water law and Indian law are different to those of Australia. Nonetheless, the rights to hunt and fish are significant for Indigenous peoples who have placed a lot of importance on these practices as an essential element of custom and tradition [30] (p. 9).

The next steps for Indigenous peoples are to develop methods for reintegrating their own approaches into mainstream management regimes, to cross artificial borders of agencies, levels of government and imposed boundaries [1]. Several Indigenous groups in Australia, the U.S. and Canada are forming community-based management organizations to respond to government management regimes and resource allocation programs, ensuring that native law and concepts of responsibility provide the basis for meaningful dialogue [30]. Hill states that:

Delivery of the potential mutual benefits for biodiversity conservation and Indigenous peoples through protected area co-management remains challenging, with partnership arrangements frequently delivering inequitable outcomes that marginalise Indigenous interests. Further investigation of the potential of Indigenous-controlled planning to build theory and practice in Indigenous co-management of protected areas is recommended. [41] (p. 72)

\section{Conclusions}

Progress towards Aboriginal partnerships in water resources management in Australia has been slow and patchy. The native title system has been the primary means of negotiating natural resource management issues for Aboriginal peoples and until recently, their involvement in water resources governance and management in Australia has not been adequately acknowledged.

Hill describes "an analysis of the negotiation and delivery of an Indigenous-controlled planning initiative in Western Australia and concluded it made a key contribution in shaping an equitable intercultural space for ongoing negotiation of co-management" [41] (p. 72). Hill also identified three significant factors in co-management: "(1) a foundation platform of recognition of rights and interests; (2) a set of effective organizations to support the roles of the key actors; and (3) effective mechanisms for working together [41] (p. 72)." Hill concluded that this model "proved robust when evaluated against international standards for best practice, suggesting it may be a useful tool for guiding better uptake of those standards" [41] (p. 72).

Most Native American tribes in the U.S. are sovereign nations, with unique systems of government, and can litigate or negotiate their water rights with the Federal Government, although this may not 
always hold true in practice. The U.S. and Canada apply inconsistent approaches to honoring water resources agreements or resolving Indian water rights issues. This scenario is likely to resonate in Australia, and therefore, there needs to be better solutions to remedy these long-term difficulties in both North America and Australia.

In Canada, Aboriginal title does not distinguish between land and water rights; water rights are a part of Aboriginal title. Canada's approach (under the 1993 Native Title Act) to water resources management with native peoples (on a case by case basis) has been to pursue negotiated agreements at regional scales that provide for shared resource control and better access between Indigenous and non-Indigenous peoples. This trend has been less litigation (as compared to the U.S.) and more negotiated agreements. However, the success of this approach has varied from region to region in Canada. Additionally, there is no comprehensive compilation of Aboriginal customary water laws for co-management arrangements; therefore, co-management arrangements remain uncertain.

The Australian model of co-management could potentially work well and, in certain cases has shown promise for long-term Indigenous co-management opportunities. In North America, ineffective policies often led to conflict with state and provincial rights which led to lengthy court battles, local disputes, and miscommunication, and some examples have not supported co-management arrangements, resulting in continuous consultation. Canada's approach-which has been influential in Australia (under Native Title) — is to try to pursue negotiated agreements at a regional scale that provide for shared resource control and access between Indigenous and non-Indigenous peoples rather than follow the U.S. model of extended negotiation and litigation. However, Canada's situation is also complex and sometimes there is heavy reliance on litigation, not simply negotiated settlements.

Reforms to improve Indigenous access to water resources management also require policies and principles to be embedded in government approaches. This view would agree with principles contained in several articles in the 2008 United Nations Declaration on the Rights of Indigenous Peoples [13]. However, written policies alone are insufficient to provide meaningful change for Indigenous people and may give the illusion of progress, which does not necessarily translate into consequential change for Indigenous people.

The legacy of colonialism in Australia, Canada, and the U.S. is a significant barrier to assertion of tribal sovereignty in areas of shared jurisdictions and watershed boundaries. A necessary paradigm shift in colonial mindsets would usher water policy reform that is respectful of sovereignty instead of dismissive. For this to take place, however, Indigenous people must have a seat at the table and demonstrate willingness to assert their sovereignty within an interjurisdictional context. This complex method of adaptive governance offers perhaps a lengthy negotiation of water rights, as exemplified in the U.S., and a process that could have long-lasting effects in the future of scarce resources, increasing populations, and additional watershed issues to tackle.

There are lessons to be learned from how communities in Australia, the United States, and Canada manage water resources and how they respond to living with each other and sharing common resources. If water is a human right, as declared by the UN, then each country must adopt co-management practices and take the next steps toward integrated water management. There must also be a broad sharing of power and responsibility between governments and resource users. This can be achieved by building linkages and decision-making structures within the management domain. This must involve community-based water initiatives such that Indigenous water rights are protected, and Indigenous peoples have a proprietary right to govern their lands and waters as they see fit. Ultimately, Indigenous peoples' self-determination and governance, as with all humans, lies in how water resources can support current and future generations.

Author Contributions: J.H.T.; J.E.B.; I.C.B.; and P.V. conceptualized the research. J.H.T prepared the draft manuscript while the review and editing were completed by J.H.T., J.L.W.; J.E.B., I.C.B., and P.V.

Funding: This research was funded by a grant from the Marine and Tropical Science and Research Facility (MTSRF), a component of the Commonwealth Environment Research Facilities Program (CERF), an initiative of the Australian Government. 
Conflicts of Interest: The authors declare no conflict of interest.

\section{References}

1. Ross, A.; Pickering, K. The Politics of reintegrating Australian Aboriginal and American Indian Indigenous knowledge into resource management: The dynamics of resource appropriation and cultural revival. Hum. Ecol. 2002, 30, 187-214. [CrossRef]

2. Bohnet, I.; Kinjun, C. Community uses and values of water informing water quality improvement planning: A study from the Great Barrier Reef region, Australia. Mar. Freshw. Res. 2009, 60, 1176-1182. [CrossRef]

3. Maclean, K.; The Bana Yarralji Bubu Inc. Crossing cultural boundaries: Integrating Indigenous water knowledge into water governance through co-research in the Queensland Wet Tropics, Australia. Geoforum 2015, 59, 142-152. [CrossRef]

4. Greiner, R.; Patterson, L.; Bligh, V.; Milligan, S. Well-Being of Traditional Owners: Contributions by Girringun Aboriginal Corporation; Burdekin Dry Tropics NRM: Townsville, Australia, 2007.

5. Hill, R.; Williams, L. Indigenous natural resource management: Overcoming marginalization produced in Australia's current NRM model. Contested Country: Local and Regional Natural Resources Management in Australia; CSIRO Publishing: Collingwood, Australia, 2009; pp. 161-178.

6. Carlsson, L.; Berkes, F. Co-Management: Concepts and methodological implications. J. Environ. Manag. 2005, 75, 65-76. [CrossRef] [PubMed]

7. Nursey-Bray, M.; Rist, P. Co-management and protected area management: Achieving effective management of a contested site, lessons from the Great Barrier Reef World Heritage Area (GBRWHA). Mar. Policy 2009, 33, 118-127. [CrossRef]

8. Cosens, B.; Chaffin, B. Adaptive governance of water resources shared with Indigenous peoples: The role of law. Water 2016, 8, 97. [CrossRef]

9. Hibbard, M.; Lane, M.B.; Rasmussen, K. The split personality of planning: Indigenous peoples and planning for land and resource management. J. Plan. Lit. 2008, 23, 136-151. [CrossRef]

10. Tehan, M.; Palmer, L.; Langton, M.; Mazel, O. Sharing land and resources: Modern agreements and treaties with Indigenous people in settler states. In Settling with Indigenous People; Langton, M., Mazel, O., Palmer, L., Shain, K., Tehan, M., Eds.; The Federation Press: Sydney, Australia, 2006; pp. 1-18.

11. Palmer, L.; Tehan, M. Shared citizenship and self-government in Canada: A case study of James Bay and Nunavik (northern Quebec). In Settling with Indigenous People; Langton, M., Mazel, O., Palmer, L., Shain, K., Tehan, M., Eds.; The Federation Press: Sydney, Australia, 2006; pp. 19-42.

12. Langton, M.; Tehan, M.; Palmer, L.; Shain, K. (Eds.) Honour among Nations; Melbourne University Press: Melbourne, Australia, 2004.

13. Jackson, S.; Tan, L.P.; Altman, J. Indigenous Fresh Water Planning Forum: Proceedings, Outcomes and Recommendations; Australian Government National Water Commission: Turner, Australia, 2009.

14. Jackson, S.; O'Leary, P. Indigenous Interests in Tropical Rivers: Research and Management Issues: A Scoping Study for Land and Water Australia's Tropical Rivers Program; Prepared for the North Australian Land and Sea Management Alliance (NAILSMA); CSIRO: Brisbane, Australia, 2006.

15. Jackson, S.; Storrs, M.; Morrison, J. Recognition of Aboriginal rights: Interests and values in river research and management: Perspectives from northern Australia. Ecol. Manag. Restor. 2005, 6, 105-110. [CrossRef]

16. Marshall, V. Overturning aqua nullius: Pathways to national law reform. In New Directions for Law in Australia: Essays in Contemporary Law Reform; Levy, R., O’Brien, M., Rice, S., Ridge, P., Thornton, M., Eds.; Australian National University Press: Canberra, Australia, 2017; pp. 176-183.

17. Escott, H.; Beavis, S.; Reeves, A. Incentives and constraints to indigenous engagement in water management. Land Use Policy 2015, 49, 382-393. [CrossRef]

18. Taylor, K.S.; Moggridge, B.J.; Poelina, A. Australian Indigenous water policy and the impacts of the ever-changing political cycle. Australas. J. Water Resour. 2016, 20, 132-147. [CrossRef]

19. Jackson, S.; Barber, M. Recognizing Indigenous water cultures and rights in mine water management: The role of negotiated agreements. Aquat. Procedia 2015, 5, 81-89. [CrossRef]

20. Brevini, B.; Woronov, T. Nothing but Truthiness: Public discourses on the Adani Carmichael Mine in Australia. In Carbon Capitalism and Communication; Palgrave Macmillan: Cham, Switzerland, 2017; pp. 147-159. 
21. Amos, C.; Swann, T. Carmichael. Context Quantifying Australia's Threat to Climate Action; The Australia Institute: Canberra, Australia, 2015.

22. Hughes, T.P.; Day, J.; Brodie, J. Securing the future of the Great Barrier Reef. Nat. Clim. Chang. 2015, 5, 508-511. [CrossRef]

23. Grech, A.; Pressey, R.L.; Day, J.C. Coal, cumulative impacts, and the Great Barrier Reef. Conserv. Lett. 2016, 9, 200-207. [CrossRef]

24. Brodie, J. Dredging the Great Barrier Reef: Use and misuse of science. Estuar. Coast. Shelf Sci. 2014, 142, 1-3. [CrossRef]

25. Grech, A.; Bos, M.; Brodie, J.; Coles, R.; Dale, A.; Gilbert, R.; Hamann, M.; Marsh, H.; Neil, K.; Pressey, R.L.; et al. Guiding principles for the improved governance of port and shipping impacts in the Great Barrier Reef. Mar. Pollut. Bull. 2013, 75, 8-20. [CrossRef] [PubMed]

26. Currell, M.J.; Werner, A.D.; McGrath, C.; Webb, J.A.; Berkman, M. Problems with the application of hydrogeological science to regulation of Australian mining projects: Carmichael mine and Doongmabulla springs. J. Hydrol. 2017, 548, 674-682. [CrossRef]

27. Brueckner, M.; Eabrasu, M. Pinning down the Social License to Operate (SLO): The problem of normative complexity. Resour. Policy 2018. [CrossRef]

28. Reddy, M.; Rosencrantz, A. Challenging the proposed Carmichael mine before the United Nations. Environ. Policy Law 2018, 48, 31-36. [CrossRef]

29. Morgan, E.; Cole-Hawthorne, R. Applying a shared understanding between aboriginal and western knowledge to challenge unsustainable neo-liberal planning policy and practices. Aust. Plan. 2016, 53, 54-62. [CrossRef]

30. Robinson, C.; Jackson, S. Indigenous Customary Governance; Northern Australia Land and Water Science Review Full Report; CSIRO: Brisbane, Australia, 2009.

31. Lingiari Foundation; The North Australian Indigenous Land and Sea Management Alliance (NAILSMA). An Overview of Indigenous Rights in Water Resources Management; NAILSMA: Canberra, Australia, 2008.

32. Ganter, E. Indigenous Participation in Coastal Management in the Northern Territory, Australia: Issues and Options. Ocean Coast. Manag. 1997, 33, 193-212. [CrossRef]

33. Cook, G. Historical Perspectives on Land Use Development in Northern Australia: With Emphasis on the Northern Territory; Northern Australia Land and Water Science Review Full Report; CSIRO: Brisbane, Australia, 2009.

34. George, M.; Innes, J.; Ross, H. Managing Sea Country Together: Key Issues for Developing Co-Operative Management for the Great Barrier Reef World Heritage Area; CRC Reef Research Centre Technical Report No. 50; CRC Reef Research Centre Ltd.: Townsville, Australia, 2004.

35. Kennett, R.; Jackson, M.; Morrison, J.; Kitchens, J. Indigenous rights and obligations to manage traditional land and sea estates in North Australia. Policy Matters 2010, 17, 135-142.

36. Rose, B. Indigenous protected areas-Innovation beyond the boundaries. In Innovations for 21st Century Conservation; Figgis, P., Fitzsimons, J., Irving, J., Eds.; IUCN National Committee Australia: Canberra, Australia, 2013; pp. 50-55.

37. Zubra, M.; Ross, H.; Izurieta, A.; Rist, P.; Bock, E.; Berkes, F. Building co-management as a process: Problem solving through partnerships in aboriginal country, Australia. Environ. Manag. 2012, 49, 1130-1142.

38. Davies, J.; Hill, R.; Walsh, F.J.; Sandford, M.; Smyth, D.; Holmes, M.C. Innovation in management plans for community conserved areas: Experiences from Australian Indigenous protected areas. Ecol. Soc. 2013, $18,14$. [CrossRef]

39. Lee, E. Protected areas, country and value: The nature-culture tyranny of the IUCN's protected area guidelines for Indigenous Australians. Antipode 2016, 48, 335-374. [CrossRef]

40. Global Environment Fund, Small Grants Program. ICCA-GSI. Available online: https://sgp.undp.org/ about-us-157/partnerships/icca-gsi.html (accessed on 29 September 2018).

41. Hill, R. Towards equity in Indigenous co-management of protected areas: Cultural planning by Miriuwung-Gajerrong people in the Kimberley, Western Australia. Geogr. Res. 2011, 49, 72-85. [CrossRef]

42. Tsatsaros, J.H.; Brodie, J.E.; Bohnet, I.C.; Valentine, P. Incorporating social, traditional and biophysical values into a water quality objectives framework for the wet tropics. In Proceedings of the 2011 Queensland Coastal Conference, Cairns, Queensland, Australia, 29-31 October 2011; ISBN 978-0-9806511-1-9.

43. Tsatsaros, J.H.; Brodie, J.E.; Bohnet, I.C.; Valentine, P. A trans-disciplinary approach for refining water quality objectives in the wet tropics, Australia. In Proceedings of the Transboundary Water Management across Borders and Interfaces (TWAM) International Conference and Workshops, Aveiro, Portugal, 
16-20 March 2013; Roebeling, P.C., Rocha, J., Teotónio, C., Alves, H., Almeida, P., Eds.; University of Aveiro: Aveiro, Portugal, 2013. ISBN 978-972-789-378-2.

44. Maclean, K.; Robinson, C. Aboriginal Knowledge Partnerships for Water Planning and Assessment in the Wet Tropics Region; CSIRO Ecosystem Sciences: Brisbane, Australia, 2011.

45. Bohnet, I.; Smith, D.M. Planning future landscapes in the wet tropics of Australia: A social-ecological framework. Landsc. Urban Plan. 2007, 80, 137-152. [CrossRef]

46. Bohnet, I.C. Integrating social and ecological knowledge for planning sustainable land and seascapes: experiences from the Great Barrier Reef Region, Australia. Landsc. Ecol. 2010, 25, 1201-1218. [CrossRef]

47. Bohnet, I.C.; Roebeling, P.; Williams, K.; Holzworth, D.; Van Grieken, M.; Pert, P.; Kroon, F.; Westcott, D.; Brodie, J.E. Landscapes toolkit-An Integrated modelling framework to assist stakeholders in exploring options for sustainable landscape development. Landsc. Ecol. 2011, 26, 1179-1198. [CrossRef]

48. Cosens, B.; Gunderson, L.; Chaffin, B.C. Introduction to the Special Feature Panarchy: Assessing legal flexibility, ecological resilience and adaptive governance in regional water systems experiencing rapid environmental change. Ecol. Soc. 2018, 23, 4. [CrossRef]

49. Notzke, C. Aboriginal Peoples and Natural Resources in Canada. Centre for Aboriginal Management Education and Training (CAMET); Claudia Notzke and Captus Press Inc.: Concord, ON, Canada, 1994.

50. Brown, J. Tribes and watersheds in Washington State. In Enduring Legacies Native Cases, The Evergreen State College; The Evergreen State University: Olympia, WA, USA, 2011.

51. Getches, D.H. Defending Indigenous water rights with the laws of a dominant culture. In Liquid Relations-Contested Water Rights and Legal Complexity; Roth, D., Boelens, R., Zwarteveen, M., Eds.; Rutgers University Press: New Brunswick, NJ, USA, 2005; pp. 44-65.

52. North Australian Indigenous Land and Sea Management Alliance (NAILSMA); The Commonwealth Scientific and Industrial Research Organization (CSIRO). Indigenous Interests and the National Water Initiative (NWI): Water Management, Reform and Implementation; Background Paper and Literature Review; CSIRO: Brisbane, Australia, 2007.

53. Knowlan, L. Customary Water Laws and Practices in Canada; The United Nations Food and Agriculture Organization: Rome, Italy, 2004.

54. Simms, R.; Harris, L.; Nadia, J.; Bakker, K. Navigating the tensions in collaborative watershed governance: Water governance and Indigenous communities in British Columbia, Canada. Geoforum 2016, 73, 6-16. [CrossRef]

55. Von der Porten, S.; de Loe, R.C. Collaborative approaches to governance for water and Indigenous peoples: A case study from British Columbia, Canada. Geoforum 2013, 50, 149-160. [CrossRef]

56. Kearney, J.; Berkes, F.; Charles, A.; Pinkerton, E.; Wiber, M. The role of participatory governance and community-based management in integrated coastal and ocean management in Canada. Coast. Manag. 2007, 35, 79-104. [CrossRef]

57. Wilson, N.J.; Inkster, J. Respecting Water: Indigenous water governance, ontologies and the politics of kinship on the ground. Nat. Space 2018, 1-23. [CrossRef]

(C) 2018 by the authors. Licensee MDPI, Basel, Switzerland. This article is an open access article distributed under the terms and conditions of the Creative Commons Attribution (CC BY) license (http://creativecommons.org/licenses/by/4.0/). 